\title{
The Persistence of Suicides in G20 Countries between 1990 and 2017: an SPSM Approach to Three Generations of Unit Root Tests
}

\author{
Izunna Anyikwa (iD) https://orcid.org/0000-0003-0948-8236 \\ Department of Economics, Faculty of Business and Economic Studies \\ Nelson Mandela University, Port Elizabeth, South Africa \\ e-mail: izunnac.anyikwa@gmail.com
}

\author{
Nicolene Hamman (iD) https://orcid.org/0000-0003-2612-897X \\ Department of Economics, Faculty of Business and Economic Studies \\ Nelson Mandela University, Port Elizabeth, South Africa \\ e-mail: s212314726@mandela.ac.za
}

\author{
Andrew Phiri iD https://orcid.org/0000-0003-1775-3546 \\ Department of Economics, Faculty of Business and Economic Studies \\ Nelson Mandela University, Port Elizabeth, South Africa \\ e-mail: phiricandrew@gmail.com
}

\begin{abstract}
Suicides represent an encompassing measure of psychological wellbeing, emotional stability as well as life satisfaction, and they have been recently identified by the World Health Organization (WHO) as a major global health concern. The G20 countries represent the powerhouse of global economic governance and hence possess the ability to influence the direction of global suicide rates. In applying the sequential panel selection method (SPSM) to three generations of unit root testing procedures, the study investigates the integration properties of suicides in $\mathrm{G} 20$ countries between 1990-2017. The results obtained from all three generations of tests provide rigid evidence of persistence within the suicides for most member states of the G20 countries, hence supporting the current strategic agenda pushed by the WHO in reducing suicides to a target rate of 10 percent. In addition, we further propose that such strategies should emanate from within G20 countries and spread globally thereafter.
\end{abstract}


Keywords: Suicides, sequential panel selection method (SPSM), nonlinear unit root tests, Fourier form unit root tests, G20 countries

JEL: C22, C32, C51, C52, I12

\section{Introduction}

According to the World Health Organisation (WHO) Mortality Database, suicides are classified as one of the leading causes of death worldwide, claiming almost a million lives every year. It has thus risen as an important public health problem and a source of concern for public health management in both developed and developing countries. Suicides, as an extreme form of mortality, encompass a broad base of psychological factors such as mental health, life satisfaction and happiness (Daly et al. 2013), and it has a profound effect not only on public health but also on social and economic spheres. Moreover, death caused by suicide, besides the emotional and psychological effects on the community, also results in a loss of potential labour force participation (Lee, Roser, and Ortiz-Ospina 2017). In 2013, the World Health Organization (WHO) launched its 'Mental Health Plan' in which member states committed themselves to reducing global suicides by 10 percent by 2020. In 2014, the WHO released its first suicide-focused report titled 'Preventing Suicides: A global imperative', in which it is recommended that member states adopt and implement national strategies aimed at combating and preventing suicides (World Health Organisation 2014).

Considering the overriding importance of suicides on a global platform, it is curious to know why very little is known and researched about suicides in the empirical economic literature. Firstly, the psychological aspect of human behaviour was earlier thought to be unnecessary for economic analysis since such measures were not backed by observable data (Case and Deaton 2013). Secondly, in many countries, suicides are considered a 'taboo' topic; hence, the collection of adequate data on suicide statistics becomes problematic. A contributing factor to this relates to media reporting on suicides, which has been shown to influence suicide behaviour, as 'careless' media reporting triggers imitation behaviour amongst vulnerable citizens (Chu et al. 2018). Thirdly, studies on suicides have been dominated by psychological sciences, which primarily depend on longitudinal analytical techniques. It is only more recently that academics have considered the use of adequate time series analysis (see Platt 1984; Platt, Micciolo, and Tansella 1992; and Phiri and Mukuku 2020 for a comprehensive review of the empirical literature).

A policy question which demands empirical attention is whether policymakers are currently in control of prevailing levels of suicides globally. Currently, a majority of the economic literature has examined the relationship between suicides and other economic factors such as income (Chuang and Huang 1997; Brainerd 2001; Neumayer 2003), unemployment (Andres 2005; Dahlberg and Lundin 2005; Phiri and Mukuku 2020), or divorce (Chuang and Huang 1997; Neumayer 2003; Andres 2005). Other stud- 
ies have even designed a so-called 'natural rate of suicides', a concept which assumes that suicides could never be zero, regardless of how ideal socioeconomic conditions are Yang and Lester (1991; 2009), Viren (1999) and Andres and Halicioglu (2011). Nevertheless, these studies do not address whether suicides will converge back to their 'natural rate' in the face of exogenous shocks to the time series. This is certainly of concern following the global disturbances recently experienced between 2007 and 2010 (i.e. US sub-prime crisis of 2007, global recession period of 2009, the Euro debt crisis of 2010, and the ongoing coronavirus pandemic) which are reportedly believed to have significantly increased global levels of suicides (Chang et al. 2013; Kawohl and Nordt 2020; McIntyre and Lee 2020). With these global shocks, it is important to know whether suicides will revert to their natural equilibrium or continue in disequilibrium until they reach a 'new equilibrium level'.

The purpose of our study is to investigate the integration properties of suicide rates in G20 countries over 1996-2017 as a means of determining whether suicides are stationary or not. As inferred in the earlier works of Nelson and Plosser (1982) and Campbell and Mankiw (1987), if a times series is found to be non-stationary, then the deviation of the series from its natural equilibrium after a shock is without bounds, and the series converges into a different equilibrium. Conversely, a mean-reverting process would imply that shocks to a time series are short-lived, and minimum intervention is required to revert a time series back to its natural equilibrium. Therefore, countries whose suicides evolve as a non-stationary process would require aggressive policy intervention in the face of a shock to the suicides whilst those countries whose suicides are stationary would require less intervention.

To the best of our knowledge, only Chang, Cai, and Chen (2017), Chen, Chang, and Lin (2018) and Akyuz, Karul, and Nazlioglu (2020) have previously attempted to address this policy concern of 'persistence in suicide rates' using appropriate time series econometric techniques albeit restricted towards the US, OECD countries and Turkey, respectively. Our paper extends on these previous works by examining the integration properties of suicides for G20 countries, using the sequential panel selection method (SPSM) of Chortareas and Kapetanois (2009). This innovative method allows us to separate a panel of G20 suicide times series into two sub-panels, the first consisting of stationary series and the second consisting of non-stationary series. Our empirical approach allows us to determine which specific G20 member states require more policy intervention in suicide prevention after a significant shock to suicides. We consider this exercise more pertinent considering the ongoing coronavirus pandemic, which has deteriorated global mental health and contributed to recent spikes in suicides (Kawohl and Nordt 2020; McIntyre and Lee 2020). To ensure the robustness of our empirical analysis, we apply the SPSM to three generations of unit root testing procedures, ranging from traditional linear unit roots to more advanced tests which account for asymmetries and structural breaks in the series.

The remainder of our paper is structured as follows. Section 2 presents the paper's theoretical framework, while the methodology is outlined in section 3 of the paper. 
Section 4 of the paper gives a brief overview of suicides in G20 countries. The empirical results are presented in section 5, and the study concludes in section 6 in the form of policy implications and recommendations for future research.

\section{Theoretical framework}

Models of suicide within the academic realm have become increasingly sophisticated since the seminal contribution of Durkheim (1897), which is widely recognised as the earliest comprehensive sociological theory of suicide. In Durkheim's model, suicides are primarily driven by two psychological factors: excess 'social integration' and 'social regulation'. Durkheim's argument is that since both economic prosperity and depression result in less social integration and regulation, then suicides will rise during these two extreme periods when compared to periods of normal economic circumstances and hence, suicides are generally considered a 'societal problem'.

Nevertheless, in the early post-Great Depression period of the late 1930s and early 1940s, researchers began to think of suicides in socioeconomic spheres. Henry and Short (1954) proposed a countercyclical theory based on a 'frustration-aggression' approach in which suicides rise during recession and fall during economic booms, with the correlation between suicides and the business cycle being more prominent for 'upper-class citizens'. Similarly, Ginsberg (1966) developed a procyclical theory which states that suicide arises from the dissatisfaction of individuals. This is directly related to the discrepancy between the actual reward of an individual and his/her level of aspiration. He argues that as the economy expands, the prosperous economic environment pushes aspirations up to a rate faster than the rewards and this resulting disparity motivates suicide.

In the mid-1970s, Hamermesh and Soss (1974) provided the first real attempt at using dynamic economic theory to explain suicides as individuals' decisions. In particular, they used the following 'neo-classical type', utility-maximizing framework in which the utility function for the average individual in a group of people with permanent income YP:

$$
U_{m}=U[C(m, Y P)-K(m)]>0,
$$

where $m$ represents his age and $K$ represents a technological relation describing the cost each period of staying alive at a minimum subsistence level. If this is the utility of the average individual age $m$ with permanent income $Y P$, then the present value of his expected lifetime utility at age $a$ is represented by the following equation:

$$
Z(a, Y P)=\int_{\alpha}^{\omega} e^{-\mathrm{r}(\mathrm{m}-\mathrm{a})} U_{m} P(m) \quad \partial \mathrm{Z} / \partial \mathrm{YP}>0, \partial \mathrm{Z} / \partial \mathrm{a}<0
$$


where $r$ is the private discount rate, $\omega$ is the highest attainable age, and $P(m)$ is the probability of surviving to age $m$ given survival to age $a$. In defining $b_{i} \sim N\left(0, \sigma^{2}\right)$ as an individual's preference for living or distaste for committing suicide, then the hypothesis of committing suicides can be given as

$$
Z_{i}(a, Y P)+b_{i}=0
$$

where equation (3) assumes that an individual commits suicide when the total discounted lifetime utility remaining reaches zero. Notably, whilst the model presented by Hamemesh and Soss (1974) can address certain questions, such as the impact of age and income on suicides, it fails to appropriately address other 'supply-side' policy-related issues, such as how changes in the availability of different suicide methods can affect the agent's choice of when and whether to commit suicide.

The demand and supply model presented by Yeh and Lester (1987) more appropriately addresses these issues. In their model, the demand-side is characterized by a positive relationship between the perceived benefits of suicide, such as alleviating suffering and the probability of committing suicide.

$$
p_{t}^{d}=\alpha_{0}+\alpha_{1} E\left(s_{t}\right) \quad \alpha_{1}>0
$$

On the other hand, the supply-side is characterized by a negative relationship between the perceived costs of suicides, such as the painfulness of committing suicide and the probability of committing suicide, i.e.

$$
p_{t}^{s}=\beta_{0}+\beta_{1} E\left(s_{t}\right) \quad \beta_{1}<0
$$

By setting $p_{t}^{d}=p_{t}^{s}$, the equilibrium suicide rate can be expressed as:

$$
s_{t}^{*}=\pi_{0}+\pi_{1} E\left(s_{t}\right),
$$

where $\pi_{0}=\left(\alpha_{0}+\beta_{0}\right) / \beta_{1}, \pi_{1}=\alpha_{1} / \beta_{1}, E\left(s_{t}\right)=v_{0}+v_{1} s_{-1}+\ldots+v_{q} s_{t-q}$ and $e_{t}$ is an error term which soaks up any shocks influencing demand-side and supply-side determinants of suicide. In further denoting ${ }_{0}^{*}=\pi_{0}+v_{0}$ and ${ }_{j}^{*}=\pi_{j} v_{j}$, for $j=1,2,3, \ldots, q$, the equilibrium suicide rate $\left(s_{t}^{*}\right)$ can be derived as:

$$
s_{t}^{*}={ }_{0}^{*}+{ }_{1}^{*} s_{t-1}+{ }_{2}^{*} s_{t-2}+\ldots+{ }_{q}^{*} s_{t-q}+e_{t}
$$

Note that equation (7) bears much structural resemblance to a standard unit root test regression, and it is on this foundation that we build our empirical framework. 


\section{Methodology}

\section{The SPSM approach}

When it comes to the testing of unit roots within a time series, the power properties of panel-based unit root testing procedures are well-acknowledged within academic circles, and yet simultaneously, concerns arise, particularly, in dealing with the 'homogeneity of results' produced by panel tests (Maddala and Wu 1999). The SPSM was developed by Chortareas and Kapetanois (2009) as an alternative to conventional panel unit root tests which fail to appropriately deal with the problem of heterogeneities existing with panel series. The authors proposed a procedure in which panel unit root testing procedures are performed sequentially on a reducing panel set of data, and in each sequence, the individual series with the highest rejection of a unit root is removed from the panel before the panel is estimated again. The main end of this procedure is a segregation of the stationary from the non-stationary series, by taking advantage of power properties provided by panel unit root tests.

In order to econometrically carry out this procedure, we assume that we have a panel series of suicides, $S_{\mathrm{i}}=\left(s_{j i}, \ldots, s_{j m}\right)$, which produces a set of individual-based unit root tests statistics, $t_{i}=\left(t_{j 1}, \ldots, t_{j m}\right)$, where $i=\left\{j_{1}, \ldots, j_{m}\right\}$, for some $M<N$. By defining $i=i^{-\mathrm{j}} \cup i^{\mathrm{j}}$, such that $i^{\mathrm{j}}=\{j\} i^{1, \mathrm{~N}}=\{1, \ldots, N\}$ our objective is to estimate a binary object, $\vartheta_{j}$, which takes the value of 1 if the series is stationary and 0 if the panel series is a unit root. We thereafter implement the following 3-step algorithm to separate the stationary from the unit root processes.

Step 1: Initially set $j=1$ and $i_{j}=\{1, \ldots, N\}$.

Step 2: Perform a decision rule in which a panel unit root tests statistic is computed over $y_{i}$, and we set $\Im i_{j}=(0, \ldots, 0)$ if the panel statistic fails to reject the unit root hypothesis, while we set $\vartheta i_{j}=1$. Only if the later condition holds do we proceed to step 3, otherwise we stop the procedure.

Step 3: Set $i_{j+1}=i_{j}^{-1}$, where 1 is the index of the individual series which produces the highest rejection of the unit root hypothesis (i.e. produces the lowest test statistic). Thereafter, make $j=j+1$ and return to step 2 and repeat the procedure.

To effectively carry out the SPSM approach, it is imperative to use a combination of the individual based unit root tests and panel-based unit root tests. The following sub-sections present these 'individual-panel' corresponding pairs of unit root testing procedures for first-, second- and third-generation unit root testing procedures.

\section{First-generation unit root tests}

The first generation of unit roots can be traced to the seminal contribution of Dickey and Fuller (1979), who specified the following autoregressive (AR) time series, $y_{i}$ :

$$
y_{t}=\rho y_{t-1}+e_{t}, \quad t=1,2, \ldots, T \text { and } e_{t} \sim N\left(0, \sigma^{2}\right)
$$


They suggest that the time series, $y_{t}$ converges to an $I(0)$ stationary process as $t \rightarrow \infty$ under the conditions $\rho<1$, while if $\rho=1$, then the series evolves as a random walk with a variance which grows exponentially as $t \rightarrow \infty$. A more generalized form of regression (8), for the case of suicide time series $\left(s_{t}\right)$, is the following Augmented Dickey-Fuller (ADF) regression:

$$
\Delta s r_{t}=\alpha_{i}+\beta_{i} s r_{t}+\sum_{j=1}^{p} s r_{t-j}+e
$$

where $\Delta s r_{t}=s r_{t}-s r_{t-1}, \alpha_{i}=(1-\rho)$, and $\sum_{j=1}^{p} s r_{t-j}$ is a truncated lag intended/designed to soak up any excess serial correlation. The DF test statistic used to test the unit root null hypothesis (i.e. $\mathrm{H}_{0}: \beta_{i}=0$ ) against the stationarity alternative (i.e. $\mathrm{H}_{1}: \beta_{i}<0$ ) is the t-ratio of the $\beta_{i}$ coefficient, i.e.

$$
\mathrm{T}=\frac{y M y_{-1}}{\sqrt{\left.{ }^{2} y_{-1-1}^{\prime} M y_{-1}\right)}}
$$

where $M=I_{T}-\tau_{T}\left(\tau_{T}^{\prime}, \tau_{T}\right)^{-1} \tau_{T}^{\prime}$ and $\sigma^{2}=\Delta y_{i} M_{x i} \Delta y_{i} /(T-1)$. The critical values used to evaluate the computed test statistic are reported in McKinnon (1994). Nevertheless, many authors have argued that the Dickey-Fuller testing procedure lacks power in distinguishing unit root processes from stationary properties, and that using panel data unit root tests is one way of increasing the power of unit root testing procedures (Maddala and Wu 1999). Levin, Lin, and Chu (2002) (LLC hereafter) suggested thE following panel unit root testing regression:

$$
\Delta s r_{i, t}=\alpha_{m i} d_{m i, t}+\beta_{i} s r_{i, t-1}+\sum_{j=1}^{p} s r_{i, t-j}+e_{i t} \text { for } i=1, \ldots, N ; t=1, \ldots, \mathrm{T}
$$

where $d_{m i}$ contains deterministic terms. LLC suggested a three-step procedure to perform the panel unit root test. i) Firstly, perform individual ADF test regressions to determine the optimal lag $(p)$. Then run two auxiliary regressions, by regressing $\Delta y_{i, t}$ and $y_{i, t-1}$ against $\Delta y_{i, t-j}(j=1, \ldots, p)$ and generate residual terms $e_{i t}$ and $v_{i t-1}$, respectively and normalize these errors. ii) Secondly, regress $e_{i t}$ on $v_{i t}$ (i.e. $e_{i, t}=\rho_{i} v_{i, t-1}+u_{i, t}$ ) and then formulate the unit root null hypothesis, tested as $\mathrm{H}_{0}: \beta_{1}=\beta_{2}=\ldots=\beta_{N}=\beta=0$ which is tested against the stationary alternative of $\mathrm{H}_{1}: \beta_{1}=\beta_{2}=\ldots=\beta_{\mathrm{N}}=\beta<0$. iii) Lastly, estimate the ratio of the long-run to short-run standard deviations which will be used to adjust the mean of the t-statistic use to test the null versus alternative hypothesis. A well-recognized limitation of the LLC test is that $\beta$ is the same for all $i$. To circumvent this, Im, Pesaran, and Shin (2003) (IPS hereafter) proposed a more general alternative hypothesis in which $\mathrm{H}_{1}: \beta_{i}<0, i, \ldots, N_{\mathrm{l}} ; \beta_{i}=0, i=N+1, \ldots, N$. As opposed 
to pooling the data, IPS estimated separate unit root tests for the $\mathrm{N}$ cross-sections and then computed the panel test statistic as:

$$
t_{N, T}=\frac{1}{N} \sum_{i=1}^{N} t_{i, L}
$$

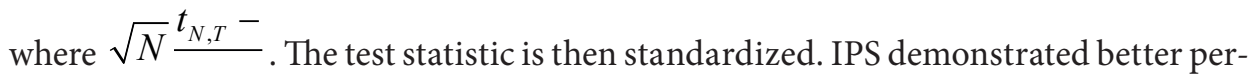
formance than the LLC test when $N$ and $T$ are small.

\section{Second-generation unit root tests}

Dissatisfied with the power properties and time series assumptions presented by the first-generation unit root tests, the second-generation unit root tests primarily dismissed the notion of linearity within time series variables in which nonlinearity may be mistaken for unit root behaviour. The most comprehensive nonlinear unit root testing procedure is outlined in Kapetanois et al. (2003) (KSS hereafter), who particularly specified the following ESTAR unit root test regression:

$$
y_{t}=\gamma_{i} y_{t-1}\left[1-\exp \left(-\Phi y_{t-1}^{2}\right)\right]+\sum_{j=1_{i}}^{p} y_{t-i}+e_{t}
$$

From equation (12), testing the unit root null hypothesis can be achieved by imposing $\Phi=0$. Yet, given the presence of nuisance parameters under the null hypothesis, it is more feasible to test for unit roots after applying a first-order Taylor approximation, resulting in the following auxiliary regression:

$$
\Delta y_{t}=\mu_{t}+\delta_{i} y_{t-1}^{3}+\sum_{j=1}^{p} y_{j}+e_{t}
$$

Henceforth the null hypothesis of a unit root is formally tested as $\mathrm{H}_{0}$ : $\delta_{i}=0$ against the ESTAR stationary alternative of a stationary process $\mathrm{H}_{1}: \delta_{i}<0$, using the following test statistic:

$$
t_{k s s}=\frac{\sum_{t=1}^{T} y_{t-1}^{3} y_{t}}{\sqrt{\hat{2} \sum_{t=1}^{T} y_{t-1}^{6}}}
$$

The obtained $t_{k s s}$ statistic is then compared against the corresponding critical values which are tabulated in Kapetanois et al. (2003). Ucar and Omay (2009) (OU hereafter) expanded the KSS testing procedure into a panel framework based on the procedure of IPS. Their baseline panel ESTAR (PESTAR) testing regression is given as: 


$$
\Delta y_{i, t}=\mu_{i, t}+\delta_{i} y_{i, t-1}^{3}+\sum_{j=1}^{p} y_{i, j}+e_{i t,-j}
$$

where the panel unit root test statistic used to test the unit root hypothesis (i.e. $\mathrm{H}_{0}: \delta_{i}=0$ ) against the nonlinear stationary alternative (i.e. $\mathrm{H}_{1}: \delta_{i}<0$,), is computed as the invariant average statistic of the individual KSS statistics for each series, i.e.

$$
t_{N L}=\frac{1}{N} \sum_{i=1}^{N} t_{i, N L}
$$

UO proposed the following five-step sieve-bootstrap algorithm to compute the panel unit root tests statistic. Firstly, estimate a univariate KSS regression (as in equation (13)) for each of the individual countries with the optimal lag of each individual regression being determined by the Schwartz criterion. Secondly, generate a series of bootstrapped errors (i.e. $e_{i, t}=\Delta y_{i, t}-\mu_{i,-} \sum_{j=1}^{p} y_{i, j}$ ) which are then centred as; $e_{i, t}=e_{i, t}-(T-p-2)^{-1} \sum_{t=p+2}^{T} e_{t}$. Thirdly, develop an $N$ by $T$ matrix for the entire panel, we then produce a series of bootstrapped error terms $e_{i, t}^{*}$, from which derive bootstrapped series of $y_{i, t}^{*}$ as:

$$
y_{i, t}^{*}=\mu_{\mathrm{i},}+\sum_{j=1}^{p} y_{i, j}^{*}+e_{i, t}^{*}
$$

Fourthly, we generate our bootstrapped sample series of $y_{i, t}^{*}$ from the partial sums i.e. $y_{i, t}^{*}$ (i.e. $y_{i, t}^{*}=\sum_{j=1} y_{i, j}^{*}$ ). Lastly, we derive the bootstrap p-values for the $t_{N L}^{*}$ statistic which are computed by running the following nonlinear regression:

$$
y_{i, t}^{*}=\mu_{i, t}+\gamma_{i}\left(y_{i, t-1}^{*}\right)^{3}+\sum_{j=1}^{p} \alpha_{i j} y_{i, t-1}^{*}+v_{i t} .
$$

\section{Third-generation unit root tests}

The third-generation unit root tests are the flexible Fourier form (FFF) type tests introduced into the econometric paradigm in the seminal work by Becker et al. (2006) and more recently popularized in the paper by Enders and Lee (2012). The idea behind these FFF-type tests is that a sequence of smooth structural breaks using the low-frequency components of a Fourier approximation (Becker et al. 2006). These tests are seen as an improvement over other structural-break unit root tests such as Perron (1989), Zivot and Andrew (1992) and Lee and Strazicich (2004; 2013), which determine structural breaks either exogenously or endogenous, the FFF function itself is not periodic such 
that the Fourier approximation can still capture the shape of unknown structural shifts in a time series. The general flexible Fourier function can be specified as follows:

$$
d(t)=\beta_{0}+\sum_{k=1}^{n} a_{k} \sin \left(\frac{2 \pi K t}{T}\right)+\sum_{k=1}^{n} b_{k} \cos \left(\frac{2 \pi K t}{T}\right), n \leq T / 2,
$$

where $\mathrm{n}$ is the number of cumulative frequency components, $\mathrm{a}$ and $\mathrm{b}$ measure the amplitude and displacement of the sinusoidal and $\mathrm{K}$ is the singular approximated frequency selected for the approximation. Becker et al. (2006) and Enders and Lee (2012) suggest the restriction of $n=1$ (i.e. single-frequency components) to circumvent over-fitting problems as well as to ensure that the evolution of the nonlinear trend is gradual over time. The resulting low-frequency component can mimic structural changes which are characterized by spectral density functions which tend towards a zero frequency. Placing the restricting $n=1$ in equation (17) and substituting the resulting regression into (13) results in the following FFF-augmented KSS 'individual' unit root testing regression:

$$
y_{t}=\delta_{i} y_{t-1}^{3}+\sum_{j=1}^{p} y_{t-j}+a_{i} \sin \left(\frac{2 \pi K t}{T}\right)+b_{i} \cos \left(\frac{2 \pi K t}{T}\right)+v_{t},
$$

while substituting into equation (14) results in the following FFF-augmented OU 'panel' unit root testing regression:

$$
y_{i, t}=\mu_{i, t}+\delta_{i} y_{i, t-1}^{3}+\sum_{j=1}^{p} y_{i, j}+a_{i} \sin \left(\frac{2 \pi K t}{T}\right)+b_{i} \cos \left(\frac{2 \pi K t}{T}\right)+v_{t}
$$

where $t=1,2, \ldots, T$ and $v_{t}$ is a $N\left(0, \sigma^{2}\right)$ process. Following the recommendations of Enders and Lee (2012), we perform a grid search for optimal values of frequency $K$ and lag length $j$, which are obtained by selecting the estimated regression which produces the lowest sum of squared residuals (SSR).

\section{Data and premilinary overview of suicide trends in G20 countries: 1991-2016}

Our empirical data, 'total suicides per 100,000 people', collected for individual G20 (minus the European Union) countries, were sourced from the Institute of Health Metrics and Evaluation (IHME, 2018) Global Burden of Disease database. The data were collected annually between 1990 and 2016. Table 1 presents the descriptive statistics of each country. In examining the overall global trends in suicide mortality rate, our empirical data suggests that on average, approximately 830,883 people died annually from suicide worldwide from 1990-2017. This corresponds to an age-standardised 
suicide mortality rate of about 14.3 per 100,000 people over the period. In 2016 , approximately 817,147 people died from suicide worldwide compared to 766,043 in 1990 . This reflects an age-standardised suicide mortality rate of about 11.2 per 100000 people in 2016.

A cursory look at the trends in the time series data for G20 countries indicates that the prevalence of suicide mortality varies considerably across countries and over time. We particularly note that the highest suicide averages are found in 4 out of the 5 members of the BRICS alliance of countries (Russia (38.23), India (20.12), China (16.11), and South Africa (17.91)) as well as for Japan (18.46) and South Korea (22.00), which are East Asian economies. On the other hand, lower, single-digit suicide averages are more prominent within Saudi Arabia (3.03) as a Middle-East representative, the three 'G20 members' of the MINT group of emerging economies (Mexico (5.18), Indonesia (3.90) and Turkey (3.93)), Brazil (6.71), as well as for Italy (6.67) and the UK (8.72). Finally, intermediate, double-digit averages of suicide rates are found in the remaining economies which are largely G7 and Latin American countries (Argentina (11.69), Australia, (11.79), Canada (12.00), the US (12.31), Germany (12.70), and France (18.91)). Note that these observations are somewhat contrary to conventional academic wisdom, which speculates on suicide mortality being more prevalent in emerging and less developed countries than in developed countries due to socioeconomic and behavioural factors, limited access to mental health care and the shortage of behavioural health care providers (Moneim, Yassa, and George 2011; Kumar et al. 2013; Kegler, Stone, and Holland 2017).

Table 1. Descriptive statistics

\begin{tabular}{|l|r|r|r|c|c|}
\hline \multicolumn{1}{|c|}{ Country } & Mean & Maximum & Minimum & $\begin{array}{c}\text { Standard } \\
\text { Deviation }\end{array}$ & $\begin{array}{c}\text { j-b } \\
\text { (p-value) }\end{array}$ \\
\hline Argentina & 11.69 & 12.53 & 10.88 & 0.53 & $2.74(0.25)$ \\
\hline Australia & 11.79 & 13.35 & 10.47 & 1.08 & $3.30(0.19)$ \\
\hline Brazil & 6.71 & 7.30 & 6.37 & 0.31 & $3.15(0.21)$ \\
\hline Canada & 12.00 & 13.22 & 10.87 & 0.91 & $2.98(0.23)$ \\
\hline China & 16.11 & 23.87 & 8.54 & 5.25 & $0.12(1.59)$ \\
\hline France & 18.91 & 23.21 & 15.31 & 2.65 & $0.24(1.67)$ \\
\hline Germany & 12.70 & 15.13 & 10.52 & 1.68 & $2.84(0.24)$ \\
\hline India & 20.12 & 21.43 & 17.90 & 1.19 & $3.28(0.19)$ \\
\hline Indonesia & 3.90 & 4.08 & 3.54 & 0.18 & $4.46(0.11)$ \\
\hline Italy & 6.67 & 8.09 & 5.62 & 0.88 & $2.83(0.24)$ \\
\hline Japan & 18.46 & 19.98 & 16.67 & 1.25 & $3.09(0.21)$ \\
\hline Mexico & 5.18 & 5.91 & 4.29 & 0.50 & $1.45(0.48)$ \\
\hline Russia & 38.23 & 48.22 & 29.30 & 6.46 & $2.68(0.26)$ \\
\hline Saudi Arabia & 3.03 & 3.78 & 2.63 & 0.33 & $1.56(0.46)$ \\
\hline South Africa & 17.94 & 21.08 & 13.74 & 2.44 & $3.06(0.22)$ \\
\hline South Korea & 22.00 & 28.07 & 14.00 & 5.22 & $3.19(0.20)$ \\
\hline Turkey & 3.93 & 4.87 & 3.01 & 0.69 & $2.87(0.24)$ \\
\hline
\end{tabular}


Table 1. (continued)

\begin{tabular}{|l|c|c|c|c|c|}
\hline \multicolumn{1}{|c|}{ Country } & Mean & Maximum & Minimum & $\begin{array}{c}\text { Standard } \\
\text { Deviation }\end{array}$ & $\begin{array}{c}\text { j-b } \\
\text { (p-value) }\end{array}$ \\
\hline UK & 8.72 & 10.03 & 7.86 & 0.77 & $3.01(0.22)$ \\
\hline US & 12.31 & 12.94 & 11.65 & 0.42 & $1.81(0.40)$ \\
\hline
\end{tabular}

Notes: Authors own computation. j-b statistic indicates that all series are normally distributed. Source: authors' own plot in eviews using suicide data from the Institute of Health Metrics and Evaluation (IHME) Global Burden of Disease database: 1990-2017.

\section{Empirical results}

\section{First-generation unit root test results}

Table 2 presents the results of the SPSM approach applied to the cluster of first-generation unit root tests, with Panel A reporting the results of the procedure performed on the pairs of unit root tests with drift, and Panel B showing the results for the procedure performed on pairs of unit roots performed with both drift and trend. To carry out the procedure, we first compute the individual ADF test statistics for each time series and report the results in a sequential format, with the series with the highest rejection or lowest test statistic being reported first (in our case, South Korea, when the tests are performed with drift, and Argentina, when the tests are performed with both drift and trend) followed by the series with the second-highest rejection 'test statistic' (which is now Brazil for the drift models and Russia for the drift and trend model), and so forth.

We then perform the panel unit root tests (LLC and IPS tests) in a similar sequential fashion, with the first-panel test statistic computed for the entire panel, then the second-panel statistic computed for the panel with the individual series yielding the highest rejection being removed from the panel, then the third-panel statistic is computed for the panel with the individual series yielding the highest and second-highest rejection rates being removed from the panel, and this procedure is carried out in this fashion of a consecutively reducing panel until we have segregated the stationary from the non-stationary panel. The optimal lag for each of the performed tests is determined by minimising the modified AIC, as suggested by Ng and Perron (2001). The results show some discrepancies in the results obtained. For instance, when the procedure is carried out with drift, the LLC statistic identifies six stationary processes (i.e. South Korea, Brazil, Japan, China, the US and France) whereas the IPS statistics find no stationary series. Nevertheless, we cannot consider these results to be conclusive since they ignore important nonlinearities and structural breaks found in the data. We address these concerns in the following sub-sections. 
Table 2. SPSM approach to ADF, LLC and IPS nonlinear unit root tests

\begin{tabular}{|c|l|l|l|l|}
\hline Sequence & $\begin{array}{c}\text { Min. ADF } \\
\text { stat }\end{array}$ & \multicolumn{1}{|c|}{ Series } & \multicolumn{1}{c|}{$\begin{array}{c}\text { LLC } \\
\text { stat }\end{array}$} & IPS stat \\
\hline 1 & $-3.22^{* *}[1]$ & South Korea & $-4.25^{* * *}(0.00)$ & $1.01(0.84)$ \\
\hline 2 & $-2.81^{*}[0]$ & Brazil & $-3.32^{* * *}(0.00)$ & $1.46(0.93)$ \\
\hline 3 & $-2.23[1]$ & Japan & $-2.83^{* * *}(0.00)$ & $1.82(0.97)$ \\
\hline 4 & $-1.95[1]$ & China & $-2.72^{* * *}(0.00)$ & $2.06(0.98)$ \\
\hline 5 & $-1.83[2]$ & US & $-1.83^{* *}(0.03)$ & $2.32(0.98)$ \\
\hline 6 & $-1.70[1]$ & France & $-1.79 * *(0.03)$ & $2.51(0.99)$ \\
\hline 7 & $-1.69[4]$ & Italy & $-0.87(0.19)$ & $2.65(0.99)$ \\
\hline 8 & $-1.62[1]$ & Germany & $-0.33(0.37)$ & $2.89(0.99)$ \\
\hline 9 & $-1.61[1]$ & UK & $-0.04(0.48)$ & $2.76(0.99)$ \\
\hline 10 & $-1.40[0]$ & Mexico & $0.92(0.82)$ & $2.92(0.99)$ \\
\hline 11 & $-1.22[2]$ & Argentina & $1.02(0.85)$ & $2.86(0.99)$ \\
\hline 12 & $-0.85[2]$ & Russia & $0.94(0.83)$ & $2.96(0.99)$ \\
\hline 13 & $-1.04[1]$ & Australia & $0.76(0.78)$ & $2.93(0.99)$ \\
\hline 14 & $-0.65[1]$ & South Africa & $1.03(0.85)$ & $3.04(0.99)$ \\
\hline 15 & $-0.55[0]$ & Turkey & $0.97(0.83)$ & $2.91(0.99)$ \\
\hline 16 & $-0.51[4]$ & Saudi Arabia & $0.98(0.84)$ & $2.71(0.99)$ \\
\hline 17 & $-0.35[0]$ & Canada & $0.84(0.80)$ & $2.70(0.99)$ \\
\hline 18 & $0.27[2]$ & Indonesia & $1.75(0.96)$ & $2.71(0.99)$ \\
\hline 19 & $0.39[1]$ & India & $1.19(0.88)$ & $2.05(0.99)$ \\
\hline
\end{tabular}

Notes: ${ }^{* * *},{ }^{* *},{ }^{*}$ represent the $1 \%, 5 \%$ and $10 \%$ critical levels, respectively. Optimal lag lengths reported in []. P-values reported in ().

Source: authors own plot in eviews using suicide data from the Institute of Health Metrics and Evaluation (IHME) Global Burden of Disease database: 1990-2017.

\section{Second-generation unit root test results}

Table 3 presents the results of the SPSM approach applied to our second-generation unit root tests of KSS (2003) and OU (2009). As before, we begin the process by computing the individual KSS statistic for each individual series, which is reported in sequence of the lowest statistic (highest rejection) to the highest test statistics (lowest rejection). The sequences, as well as the estimated values of these individual statistics, are found in the first three columns of Table 3. After that, we apply the OU sieve bootstrap procedure to compute the corresponding OU panel statistic, firstly for the entire panel, and then on a reducing panel set in which individual series with the highest rejection are sequentially removed until we effectively segregate the stationary from the non-stationary panel. These panel unit root statistics are reported in the fourth column of Table 3 whilst the bootstrap p-values and the associate optimal lags lengths are found in the fifth and sixth columns of Table 3, respectively.

After completing the procedure, we find the panel of stationary time series for 11 of the G20 countries (the United Kingdom, Brazil, Indonesia, France, Italy, Chi- 
na, Australia, Canada, Germany, Russia and India) while the remaining countries (Turkey, South Africa, South Korea, Argentina, Japan, the United States, Saudi Arabia and Mexico) exhibit non-stationary behaviour. Interestingly, the stationary panel consists of six advanced and five emerging economies of the G20 panel, while the non-stationary panel primarily consists of emerging non-G7 member states. We also note that these results can also be compared to those obtained in the previous study of Chang et al. (2017), who used a similar SPSM framework applied to a sample of 23 OECD countries of which six of these countries (the United Kingdom, France, Italy, Canada, Japan and the United States) belong to our panel of G20 countries. However, in contrast to Chang, Cai, and Chen (2017), who found unit root behaviour for all these 'commonly sampled' economies, our current findings point to stationarity in five out of six of these countries.

Table 3. SPSM approach to OU and KSS nonlinear unit root tests

\begin{tabular}{|c|l|c|c|c|c|}
\hline Sequence & \multicolumn{1}{|c|}{ Series } & Min. KSS & OU statistic & p-value & Lag \\
\hline 1 & UK & $-6.89^{* * *}$ & $-2.19^{* *}$ & 0.02 & 0 \\
\hline 2 & Brazil & $-5.65^{* * *}$ & $-2.18^{* *}$ & 0.02 & 0 \\
\hline 3 & Indonesia & $-4.14^{* * *}$ & $-2.17^{*}$ & 0.03 & 0 \\
\hline 4 & France & $-3.62^{* * *}$ & $-2.14^{*}$ & 0.04 & 3 \\
\hline 5 & Italy & $-3.30^{* * *}$ & $-2.09^{*}$ & 0.04 & 1 \\
\hline 6 & China & $-2.79^{* * *}$ & $-1.92^{*}$ & 0.06 & 1 \\
\hline 7 & Australia & $-2.28^{* *}$ & $-1.91^{*}$ & 0.06 & 4 \\
\hline 8 & Canada & $-2.05^{*}$ & $-1.86^{*}$ & 0.06 & 2 \\
\hline 9 & Germany & -1.76 & $-1.79^{*}$ & 0.08 & 6 \\
\hline 10 & Russia & -1.75 & $-1.78^{*}$ & 0.08 & 4 \\
\hline 11 & India & -1.72 & $-1.68^{*}$ & 0.09 & 1 \\
\hline 12 & Turkey & -1.43 & -1.64 & 0.10 & 0 \\
\hline 13 & South Africa & -1.09 & -1.61 & 0.10 & 1 \\
\hline 14 & South Korea & -0.97 & -1.61 & 0.11 & 1 \\
\hline 15 & Argentina & -0.68 & -1.55 & 0.12 & 2 \\
\hline 16 & Japan & -0.24 & -1.26 & 0.21 & 1 \\
\hline 17 & US & -0.15 & -0.71 & 0.48 & 2 \\
\hline 18 & Saudi Arabia & 0.15 & -0.26 & 0.79 & 0 \\
\hline 19 & Mexico & 0.92 & -0.21 & 0.78 & 1 \\
\hline
\end{tabular}

Notes: ${ }^{* * *},{ }^{* *},{ }^{*}$ represent the $1 \%, 5 \%$ and $10 \%$ critical levels, respectively. p-values for OU statistic generated through a bootstrap of 10,000 replications.

Source: authors own plot in eviews using suicide data from the Institute of Health Metrics and Evaluation (IHME) Global Burden of Disease database: 1990-2017. 


\section{Third-generation unit root test results}

Table 4 presents the results for the SPSM applied to the third-generation unit root testing procedure. These tests vary from the first- and second-generation tests by including a flexible Fourier approximation to the unit root tests which, by design, are intended to capture a series of unobserved, smooth structural breaks and have been demonstrated to be more powerful than other structural breaks or nonlinear unit root tests (Becker et al. 2006; Enders and Lee 2012). Recall that the procedure is carried out by first estimating individual KSS-FFF test statistics for the individual countries and then arranging these test statistics in order of lowest to highest values. The results of this exercise are reported in the first three columns of Table 4. Then the OU bootstrap procedure is carried out as previously, first for the whole panel, then on a reducing panel in which the KSS-FFF statistic with the highest rejection is sequentially removed in each stage of the estimation process.

The obtained panel statistics are found in column four of Table 4, and the bootstrap p-values are given in column five. The findings of the grid search to identify the optimal frequency component, $k^{\star}$, and lag length, are reported in columns six and seven, respectively. In a nutshell, our results point to a stationary panel of countries inclusive of Brazil, Russia, Japan, Canada and China, whilst the non-stationary panel consists of Argentina, the United States, South Africa, Saudi Arabia, Australia, Indonesia, Turkey, France, South Korea, India, Italy, Mexico, the United Kingdom and Germany. Notice that the stationary panel is smaller than that obtained for the KSS test performed without a FFF approximation, and this panel consists of 3 of the BRICS member states and two G7 member states. Further note that these findings are now more similar to those of Chang, Cai, and Chen (2017), who also found that by including a FFF approximation in the testing procedure, most industrialized countries fall under the non-stationary panel of suicides. Overall, these findings highlight the importance of accounting for both nonlinearities and smooth structural breaks in distinguishing stationary from non-stationary series when checking the integration properties of suicides.

Table 4. SPSM approach to OU-FFF and KSS-FFF nonlinear unit root tests

\begin{tabular}{|c|l|c|c|c|c|c|}
\hline Sequence & \multicolumn{1}{|c|}{ Series } & Min. KSS & OU statistic & p-value & K$^{*}$ & Lag \\
\hline 1 & Brazil & $-4.61^{* * *}$ & $-2.05^{*}$ & 0.04 & 1 & 5 \\
\hline 2 & Russia & $-4.19^{* * *}$ & $-2.01^{*}$ & 0.04 & 1 & 6 \\
\hline 3 & Japan & $-4.18^{* * *}$ & $-1.98^{*}$ & 0.05 & 5 & 6 \\
\hline 4 & Canada & $-3.40^{* * *}$ & $-1.93^{*}$ & 0.05 & 5 & 6 \\
\hline 5 & China & $-3.01^{* * *}$ & $-1.87^{*}$ & 0.06 & 5 & 6 \\
\hline 6 & Argentina & $-2.93^{* * *}$ & -1.51 & 0.13 & 5 & 5 \\
\hline 7 & US & $-2.42^{* * *}$ & -1.36 & 0.18 & 5 & 6 \\
\hline 8 & South Africa & $-2.39^{* *}$ & -1.32 & 0.19 & 5 & 6 \\
\hline 9 & Saudi Arabia & $-1.80^{*}$ & -1.29 & 0.19 & 5 & 6 \\
\hline
\end{tabular}


Table 4. (continued)

\begin{tabular}{|c|l|c|c|c|c|c|}
\hline Sequence & \multicolumn{1}{|c|}{ Series } & Min. KSS & OU statistic & $\mathbf{p}$-value & $\mathbf{K}^{*}$ & Lag \\
\hline 10 & Australia & -1.59 & -1.28 & 0.20 & 5 & 5 \\
\hline 11 & Indonesia & -1.55 & -126 & 0.21 & 5 & 6 \\
\hline 12 & Turkey & -1.33 & -1.26 & 0.21 & 5 & 6 \\
\hline 13 & France & -1.17 & -1.25 & 0.21 & 5 & 5 \\
\hline 14 & South Korea & -1.08 & -1.23 & 0.22 & 5 & 6 \\
\hline 15 & India & -0.22 & -1.22 & 0.22 & 5 & 6 \\
\hline 16 & Italy & 0.29 & -1.21 & 0.23 & 5 & 6 \\
\hline 17 & Mexico & 0.38 & -0.90 & 0.37 & 5 & 6 \\
\hline 18 & UK & 1.71 & -0.73 & 0.46 & 5 & 6 \\
\hline 19 & Germany & 2.72 & -0.68 & 0.51 & 5 & 6 \\
\hline
\end{tabular}

Notes: ${ }^{* * *},{ }^{* *},{ }^{*}$ represent the $1 \%, 5 \%$ and $10 \%$ critical levels, respectively. p-values for OU statistic generated through a bootstrap of 10,000 replications.

Source: authors own plot in eviews using suicide data from the Institute of Health Metrics and Evaluation (IHME) Global Burden of Disease database: 1990-2017.

\section{Conclusion}

Primarily motivated by the lack of empirical evidence due to the novelty of the field in the research study, we have investigated the possibility of persistence in suicides in G20 countries between 1990 and 2017. We consider this research worthwhile since suicides have been recently identified by the World Health Organization as one of the leading causes of mortalities globally. The selection of the G20 countries as a case study is important since these countries are currently the centre of global economic dominance and hence the potential influence of these countries in reducing global suicides cannot be overlooked or taken for granted. Previous studies examined possible persistence in suicides for the US, OECD countries and Turkey; hence, they lacked a global outlook on the subject matter. Empirically, we rely on the SPSM approach of Chortareas and Kapetanois (2009), which we apply to three generations of unit root tests, i.e., i) conventional unit root tests, ii) nonlinear unit root tests and iii) FFF-based nonlinear unit root tests. After controlling for nonlinearities and smooth structural breaks in the data, we find that only Brazil, Russia, Japan, Canada and China have stationary suicides whilst we fail to find any convincing evidence of stationarity amongst the remaining countries, which are mainly industrialized, G20 member states.

There are some important policy implications which can be gathered from our findings. For starters, we concur with the WHO and particularly advise that more advanced members of the G20 countries should move toward adopting formal national suicide prevention strategies which are tailored according to each of the members' social, religious and economic standards. Other non-G20 countries could then 'copy' the strategies implemented by G20 countries by identifying with member states that 
best correspond with their social, economic, religious and regional standings. Such suicide prevention strategies should primarily emanate from health and social ministries within each economy and then spread across different sectors of the economy, primarily the health care sector, business sector, education sector (primary, secondary and tertiary levels of education), as well within local communities. As detailed in the WHO's Mental Health Plan report (2013), prevention strategies could include surveillance measures, means restrictions, media guidelines, stigma reduction, as well as raising public awareness and training.

From an empirical standpoint, a comprehensive system of adequate data collection should be put into place by the G20 as well as non-G20 member states. It could provide a rich source of suicide numbers across the different sexes, races, age groups, religious backgrounds and other relevant socio-demographic factors. This would require more rigid data-collecting institutional structures dedicated to collecting and processing such time series, which would, in turn, naturally enrich the future academic path of research on suicides as well as forecasting practices, not only for G20 countries but other less researched recognized economies in less developed regions of the world. However, with the currently available data, one possible avenue for near-future research would be to extend upon the current knowledge on the so-called 'natural-rate of suicides' literature, which could be perceived as a natural extension of the knowledge gained from investigating the persistence of suicides.

\section{References}

Akyuz, M., Karul, C., Nazlioglu, S. (2020), Dynamics of suicide in Turkey: An empirical analysis, "EMHJ", 27 (10), pp. 1184-1192, https://doi.org/10.26719/emhj.20.033

Andres, A. (2005), Income equality, unemployment and suicide: a panel data analysis of 15 European countries, "Applied Economics", 37 (4), pp. 439-451, https://doi.org /10.1080/0003684042000295304

Andres, A., Halicioglu, F. (2011), Testing the hypothesis of the natural suicide rates: Further evidence from OECD data, "Economic Modelling", 28 (1-2), pp. 22-26, https:// doi.org/10.1016/j.econmod.2010.10.004

Becker, R., Enders, W., Lee, J. (2006), A stationarity test in the presence of an unknown number of smooth breaks, "Journal of Time Series Analysis", 27 (3), pp. 381-409, https://doi.org/10.1111/j.1467-9892.2006.00478.x

Brainerd, E. (2001), Economic reform and mortality in the former Soviet Union: A study of the suicide epidemic in the 1990s, "European Economic Review", 87 (4-6), pp. 1007-1019, https://doi.org/10.1016/S0014-2921(01)00108-8

Campbell, J., Mankiw, G. (1987), Are output fluctuations transitory?, "The Quarterly Journal of Economics", 102 (4), pp. 857-880, https://doi.org/10.2307/1884285

Case, A., Deaton, A. (2015), Suicide, age, and wellbeing: An empirical investigation, "NBER Working Paper", No. 21279, June, https://doi.org/10.3386/w21279 
Chang, S., Stuckler, D., Yip, P., Gunnell, D. (2013), Impact of the 2008 global economic crisis on suicide: Time trend study in 54 countries, "British Medical Journal", 347 (f5239), pp. 1-15, https://doi.org/10.1136/bmj.f5239

Chang, T., Cai, Y., Chen, W. (2017), Are suicide rate fluctuations transitionary or permanent? Panel KSS unit root test with a Fourier function through the sequential panel selection method, "Romanian Journal of Economic Forecasting", 20 (3), pp. 5-17, http://www.ipe.ro/rjef/rjef3_17/rjef3_2017p5-17.pdf (accessed: 25.02.2020).

Chen, W., Chang, T., Lin, Y. (2018), Investigating the persistence of suicide in the United States: Evidence from the quantile unit root test, "Social Indicators Research", 135 (2), pp. 813-833, https://doi.org/10.1007/s11205-016-1492-1

Chortareas, G., Kapetanois, G. (2009), Getting PPP right: Identifying mean-reverting real exchange rates in panels, "Journal of Banking and Finance", 30 (2), pp. 390-404, https://doi.org/10.1016/j.jbankfin.2008.08.010

Chu, X., Zhang, X., Cheng, P., Schwebel, D., Hu, G. (2018), Assessing the use of media reporting recommendations by the World Health Organization in suicide news published in the most influential media sources in China, 2003-2015, "International Journal of Environmental Research and Public Health”, 15 (451), pp. 1-12, https:// doi.org/10.3390/ijerph15030451

Chuang, H., Huang, W. (1997), Economic and social correlates of regional suicide rates: A pooled cross-section and time-series analysis, "Journal of Socio-Economics", 26 (3), pp. 277-289, https://doi.org/10.1016/S1053-5357(97)90021-4

Dahlberg, M., Lundin, D. (2005), Antidepressants and the suicide rate: Is there really a connection?, "Advances in Health Economics and Health Services Research", 16, pp. 121-141, https://doi.org/10.1016/S0731-2199(05)16006-3

Daly, M., Oswald, A., Wilson, D., Wu, S. (2013), Dark contrasts: the paradox of high rates of suicides in happy places, "Journal of Economic Behaviour and Organization”, 80 (3), pp. 435-442, https://doi.org/10.1016/j.jebo.2011.04.007

Dickey, D., Fuller, W. (1979), Distribution of the estimators for autoregressive time series with unit root, "Journal of American Statistical Association”, 74 (366), pp. 427-431, https://doi.org/10.1080/01621459.1979.10482531

Durkheim, E. (1897), Suicide, Translated by J. Spaulding and G. Simpson, Free Press, Glencore.

Enders, W., Lee, J. (2012), A unit root test using a Fourier series to approximate smooth breaks, "Oxford Bulletin of Economics and Statistics", 74 (4), pp. 574-599, https:// doi.org/10.1111/j.1468-0084.2011.00662.x

Ginsberg, R. (1966), Anomic and aspiration: a reinterpretation of Durkheim's theory, Dissertations on sociology, Columbia University, New York.

Hamermesh, D., Soss, N. (1974), An economic theory of suicide, "Journal of Political Economy”, 82 (1), pp. 83-98, https://doi.org/10.1086/260171

Henry, A., Short, J. (1954), Suicide and homicide, Free Press, Glencore.

Im, K., Pesaran, M., Shin, Y. (2003), Testing for unit roots in heterogeneous panels, "Journal of Econometrics", 115 (1), pp. 53-74, https://doi.org/10.1016/S0304-4076 (03)00092-7

Institute of Health Metrics and Evaluation (2018), Global Burden of Disease (GBD) database, http://www.healthdata.org (accessed: 25.02.2020). 
Kapetanois, G., Shin, Y., Snell, A. (2003), Testing for a unit root in the nonlinear STAR framework, "Journal of Econometrics", 112 (2), pp. 359-379, https://doi.org/10.1016 /S0304-4076(02)00202-6

Kawohl, W., Nordt, C. (2020), COVID-19, unemployment, and suicide, "Lancet Psychiatry”, 7 (5), pp. 389-390, https://doi.org/10.1016/S2215-0366(20)30141-3

Kegler, S., Stone, D., Holland, K. (2017), Trend in suicide by level of urbanization - United States, 1999-2015, "Morbidity and Mortality Weekly", 66 (10), pp. 270-273, https://doi.org/10.15585/mmwr.mm6610a2

Kumar, S., Verma, A., Bhattacharya, S., Rathore, S. (2013), Trends in rates and methods of suicide in India, "Egyptian Journal of Forensic Sciences", 3 (3), pp. 75-80, https:// doi.org/10.1016/j.ejfs.2013.04.003

Lee, J., Strazicich, M. (2004), Minimum Lagrange multiplier unit root with two structural breaks, "The Review of Economics and Statistics”, 85 (4), pp. 1082-1089, https:// doi.org/10.1162/003465303772815961

Lee, J., Strazicich, M. (2013), Minimum LM unit root with one structural break, "Economics Bulletin”, 33 (4), pp. 2483-2493, http://www.accessecon.com/Pubs/EB/20 13/Volume33/EB-13-V33-I4-P234.pdf (accessed: 25.02.2020).

Lee, L., Roser, M., Ortiz-Ospina, E. (2015), Suicide, http://ourworldindata.org/suicide (accessed: 25.02.2020).

Levin, A., Lin, C., Chu, J. (2002), Unit root tests in panel data: asymptotic and finite-sample properties, "Journal of Econometrics", 108 (1), pp. 1-24, https://doi.org /10.1016/S0304-4076(01)00098-7

Maddala, G., Wu, S. (1999), A comparative study of unit root tests with panel data and a new simple test, "Oxford Bulletin of Economics and Statistics", 61 (51), pp. 631-652, https://doi.org/10.1111/1468-0084.61.s1.13

McIntyre, R., Lee, Y. (2020), Projected cases in suicide in Canada as a consequence of COVID-19, "Psychiatry Research", 290, pp. 1-3, https://doi.org/10.1016/j.psych res.2020.113104

McKinnon, J. (1994), Approximate asymptotic distribution functions for unit-root and cointegration tests, "Journal of Business and Economic Statistics", 12 (2), pp. 167176, https://doi.org/10.1080/07350015.1994.10510005

Moneim, W., Yassa, H., George, S. (2011), Suicide rate: trends and implications in Upper Egypt, "Egyptian Journal of Forensic Sciences", 1 (1), pp. 48-52, https://doi.org /10.1016/j.ejfs.2011.04.010

Nelson, C., Plosser, C. (1982), Trends and random walks in macroeconomic time series: Some evidence and implications, "Journal of Monetary Economics", 10 (2), pp. 139162, https://doi.org/10.1016/0304-3932(82)90012-5

Neumayer, E. (2003), Socioeconomic factors and suicide at large unit aggregate levels: a comment, "Urban Studies", 40 (13), pp. 2769-2796, https://doi.org/10.1080/0042 098032000191029

Ng, S., Perron, P. (2001), Lag length selection and the construction of unit root tests with good size and power, "Econometrica", 69 (6), pp. 1519-1554, https://doi.org/10.1111 /1468-0262.00256

Perron, P. (1989), The great crash, the oil price shock, and the unit root hypothesis, "Econometrica", 57 (6), pp. 1361-1401, https://doi.org/10.2307/1913712 
Phiri, A., Mukuku, D. (2020), Does unemployment aggravate suicide rates in South Africa? Some empirical evidence, "Review of Social Economy", 78 (4), pp. 532-560 https://doi.org/10.1080/00346764.2019.1630667

Platt, S. (1984), Unemployment and suicidal behaviour: A review of the literature, “Social Science and Medicine", 19 (2), pp. 93-115, https://doi.org/10.1016/02779536(84)90276-4

Platt, S., Micciolo, R., Tansella, M. (1992), Suicide and unemployment in Italy: Description, analysis and interpretation of recent trends, "Social Science and Medicine", 34 (11), pp. 1191-1201, https://doi.org/10.1016/0277-9536(92)90312-E

Ucar, N., Omay, T. (2009), Testing for a unit root in nonlinear heterogenous panels, "Economics Letters", 104 (1), pp. 5-8, https://doi.org/10.1016/j.econlet.2009.03.018

Viren, M. (1999), Testing the "natural rate of suicide" hypothesis, "International Journal of Social Economics”, 26 (12), pp. 1428-1440, https://doi.org/10.1108/0306829 9910370535

World Health Organisation (2013), Mental health action plan 2013-2020, https://www .who.int/publications/i/item/9789241506021 (accessed: 25.02.2020).

World Health Organisation (2014), Preventing suicide: A global imperative, https://www .who.int/mental_health/suicide-prevention/world_report_2014/en/\#: :text=It\%20 aims\%20to\%20increase\%20awareness,in\%20a\%20multisectoral\%20public\%20he alth (accessed: 25.02.2020).

World Health Organisation (2018), World Health Statistics database, https://www.who .int/data/collections (accessed: 25.02.2020).

Yang, B., Lester, D. (1991), Is there a natural suicide rate for society?", "Psychological Reports", 68, https://doi.org/10.2466/pr0.1991.68.1.322

Yang, B., Lester, D. (2009), Is there a natural suicide rate?, "Applied Economic Letters", 16 (2), pp. 137-140, https://doi.org/10.1080/13504850601018189

Yeh, B., Lester, D. (1987), An economic model for suicide, [in:] D. Lester (ed.), Suicide as a learned behaviour, Springfield, Cambridge University Press.

Zivot, E., Andrew, D. (1992), Further evidence on the Great Crash, the oil-price shock, and the unit-root hypothesis, "Journal of Business and Economic Statistics", 10 (3), pp. 251-270, https://doi.org/10.1080/07350015.1992.10509904 


\section{Utrzymywanie się samobójstw w krajach G20 w latach 1990-2017: podejście SPSM do trzech generacji testów pierwiastka jednostkowego}

Samobójstwa stanowią wszechstronną miarę dobrego samopoczucia psychicznego, stabilności emocjonalnej, a także satysfakcji z życia, a ostatnio zostały uznane przez Światową Organizację Zdrowia (WHO) za główny problem zdrowotny na świecie. Państwa G20 są potęgą w obszarze globalnego zarządzania polityką gospodarczą, a tym samym mają zdolność wpływania na kształtowanie się globalnego wskaźnika samobójstw. Stosując metodę SPSM do trzech generacji testów pierwiastka jednostkowego, w opracowaniu zbadano własności integracyjne samobójstw w krajach G20 w latach 1990-2017. Wyniki uzyskane ze wszystkich trzech generacji testów dostarczają mocnych dowodów na utrzymywanie się samobójstw w większości państw członkowskich G20. Uzasadnia to istnienie aktualnego programu strategicznego forsowanego przez WHO, zmierzającego do redukcji odsetka samobójstw do docelowego poziomu 10 procent. Wskazano ponadto, że takie strategie powinny rozprzestrzeniać się z państw G20 na pozostałe państwa świata.

Słowa kluczowe: samobójstwa, metoda SPSM, nieliniowe testy pierwiastka jednostkowego, testy pierwiastka jednostkowego w postaci Fouriera, państwa G20 